\title{
Ovarian Development of Conger Eel in Korea, Conger myriaster, in Captivity
}

\author{
Se-Un Ki ${ }^{1,2}$, Chung-Kug Park ${ }^{2}$, Kyoung-Woo Lee ${ }^{2}$, Kyoung-Sik Lee ${ }^{2}$, Joon-Taek Park², \\ and ${ }^{\dagger}$ Won-Kyo Lee ${ }^{1}$
}

'Dept. of Aquaculture, Chonnam National University, Yeosu 59626, Korea

${ }^{2}$ Jeollanamdo Institute of Ocean and Fisheries Science, Wando 59116, Korea

Received: September 8, 2021

Revised: November 20, 2021

Accepted: December 17, 2021

${ }^{\dagger}$ Corresponding author

Won-Kyo Lee

Dept. of Aquaculture, College of Fisheries and Ocean Sciences, Chonnam National

University, Yeosu 59626, Korea.

Tel: +82-61-659-7161

Fax: +82-61-659-7169

E-mail:wklee196@jnu.ac.kr

Copyright ๑ 2021 The Korean Society of Developmental Biology.

This is an Open Access article distributed under the terms of the Creative Commons Attribution Non-Commercial License (http://creativecommons.org/licenses/ by-nc/4.0/) which permits unrestricted non-commercial use, distribution, and reproduction in any medium, provided the original work is properly cited.

ORCID

Se-Un Ki

https://orcid.org/0000-0003-2842-000X

Chung-Kug Park

https://orcid.org/0000-0002-7296-0719

Kyoung-Woo Lee

https://orcid.org/0000-0002-5428-4972

Kyoung-Sik Lee

https://orcid.org/0000-0001-5930-4568

Joon-Taek Park

https://orcid.org/0000-0002-1997-1769

Won-Kyo Lee

https://orcid.org/0000-0002-0303-3129

Conflict of interests

The authors declare no potential conflict of interest.

Acknowledgements

This work was supported by the Grant of the Jeollanam-do Institute of Oceans and Fisheries Science in 2021.

Authors' contributions

Conceptualization: Ki SU, Lee WK

Data curation: Ki SU, Park CK, Lee WK.

Formal analysis: Ki SU.

Methodology: Ki SU, Park CK, Lee WK.

\section{Abstract}

Effects of water temperature and hormones on ovarian development of conger eel in Korea were investigated. Ovarian development was analyzed by measuring gonadosomatic index (GSI) and oocyte diameter with histological methods. At rearing water temperatures of $12^{\circ} \mathrm{C}, 14^{\circ} \mathrm{C}$, and $16^{\circ} \mathrm{C}, \mathrm{GSI}$ value increased from 3.66 at the start of the experiment to 7.44 , 8.82 , and 7.34 at the end of the experiment, respectively. At rearing water temperatures of $12^{\circ} \mathrm{C}, 14^{\circ} \mathrm{C}$, and $16^{\circ} \mathrm{C}$, egg diameter increased from $245.11-300.25 \mu \mathrm{m}$ at the start of the experiment to $377.62-480.27 \mu \mathrm{m}, 396.72-498.54 \mu \mathrm{m}$, and 382.29-475.69 $\mu \mathrm{m}$ at the end of the experiment, respectively. Follicular oocyte development revealed that primary yolk globule stage observed from January to March. It entered to secondary yolk globule stage in April and remained at the same stage until July. As a result of examining effects of three hormones (human chorionic gonadotropin (HCG), luteinizing hormone releasing hormone analogue (LHRHa), and salmon pituitary extraction (SPE) on ovarian development, HCG was found to be the most effective one. The progress from diapause of the secondary yolk globule stage to migratory nucleus stage of oocytes could be induced by treating fish with HCG at 1,000 IU/ $\mathrm{kg}$. The effect of hormone treatment on ovarian development of conger eel in Korea was the most effective at water temperature of $14^{\circ} \mathrm{C}$.

Keywords: Conger eel, Conger myriaster, Ovarian development, Water temperature, Exogenous hormone

\section{INTRODUCTION}

The conger eel, Conger myriaster, is a marine eel species widely distributed in temperate regions from East China Sea to coastal waters of Korea and Japan (Park, 2001; Tokimura, 2001). It is mainly inhabited in shallow coastal waters to the continental shelf of the East China Sea (Ochiai \& Tanaka, 1986). C. myriaster is an important fishery resource in Korea,Japan, and China. In Japan, resource of $C$. myriaster has recent decreased, emphasizing the necessity of management and conservation of major fishing grounds. There is a need for enhanced management to ensure the maintenance of resources with sustainable supply. Proper management of $C$. myriaster stock needs to enable understating of its population dynamics. Reproduction of the fish is the only way to provide a new generation necessary to sustain its population. Therefore, understanding the reproduction of a stock is essential to unravel population dynamics. 
Software: Ki SU, Park CK.

Validation: Lee KS, Park JT, Lee KY.

Investigation: Ki SU, Park CK.

Writing-original draft: Ki SU, Lee WK.

Writing-review \& editing: Ki SU, Lee WK.

Ethics approval

This article does not require IRB/IACUC approval

because there are no human and animal participants.
Mature individuals of C. myriaster in natural population have not been collected from coastal waters to the continental margin, where many adults are caught commercially. Knowledge on the reproduction of Japanese C. myriaster has been rapidly increasing from studies of fish in captivity. The Japanese conger eel puberty begins at the age of 2 years. Its annual reproductive cycle progresses even in cultured conditions, although oocyte maturation and ovulation have not occurred yet (Utoh et al., 2004, 2005). Oocyte maturation and ovulation of Japanese conger eel can be induced by repeated injections of human chorionic gonadotropin (HCG) as an exogenous hormone in two weeks interval followed by an injection of maturation inducing steroids (Horie et al., 2001, 2003). Maturation and ovulation of female conger eel can also be induced by manipulation of water temperature manipulation without exogenous hormone treatment (Utoh et al., 2013). It is also reported that oocyte maturation and ovulation in female conger eel can be induced by single injections of HCG followed by a booster injection of HCG and then an injection of maturation inducing steroids (Fueda et al., 2019). Although these reports demonstrated the possibility of developing seed production in this species, successful fertilization of eggs for seed production were rare. To develop a seed production technique for this species, it is necessary to improve the method for obtaining fertilized eggs in terms of quality and quantity.

C. myriaster is one of most important commercial fish species in Korea. The annual yield of fisheries were 12,600 tons in 2015 and 11,992 tons in 2020 (Statistics Korea, 2015, 2020). The conger eel is a species of high value not only as a major fishery species, but also as a new aquaculture species in Korea. Despite its importance, studies on the reproduction of conger eel in Korea have not been reported yet. To develop a method to obtain fertilized eggs, the present study examined ovarian development and performed induction of oocyte maturation and ovulation of Korean $C$. myriaster in captivity.

\section{MATEIALS AND METHODS}

\section{Experimental fish}

A total of 250 female conger eels (61-87 cm in total length, 343-1,381 $\mathrm{g}$ in weight) were obtained from an aquafarm in Goheung-gun, Jeonnam province, Korea in January 2021. They were transported to maritime and fisheries museum in Yeosu-city Jeonnam province, divided into three groups, and kept in three indoor tanks $(3 \times 3 \times 1.5 \mathrm{~m})$ containing seawater. They were fed with commercial pellets for Japanese eel throughout the experimental period.

\section{Temperature effect on ovarian development}

To examine effects of water temperatures on ovarian development of female conger eels, they were divided into three water temperature $\left(12{ }^{\circ} \mathrm{C}, 14^{\circ} \mathrm{C}\right.$, and $\left.16^{\circ} \mathrm{C}\right)$ groups and reared for six months. The objective water temperature was reached by increasing the temperate at $0.5^{\circ} \mathrm{C}$ per day from $7^{\circ} \mathrm{C}$ at the commencement of the experiment. From January to July 2021, we conducted monthly sampling until April and then carried out the last sampling in July (three months later). Ten females were sacrificed after anesthetizing them with $0.1 \%(\mathrm{v} / \mathrm{v})$ 2-phenoxy-ethanol (Sigma-Aldrich, St. Louis, MO, USA ). Ovaries were removed and weighed to determine the gonadosomatic index (GSI=100 gonad weight/body weight). These dissected ovaries were measured to determine the diameter of the largest group of oocytes, fixed in Bouin's solution for 24 hours, embedded in paraffin, sectioned serially at $5 \mu \mathrm{m}$ in thickness, and then double stained with hematoxylin and eosin. Oocyte developmental stages were determined histologically as reported previously for the common Japanese conger eel (Utoh et al., 2003). 


\section{Exogenous hormonal injection}

To induce oocyte maturation and ovulation of female conger eels, we conducted two experiments. Fish were anesthetized with $0.1 \%$ (v/v) 2-phenoxy-ethanol (Sigma-Aldrich) and their body weights were measured. In the first experiment, each of 10 females were intraperitoneally injected with HCG (Daesung Microbiological Labs, Korea) at $100 \mathrm{IU} / \mathrm{kg}$ or $500 \mathrm{IU} / \mathrm{kg}$ weekly for 9 weeks followed by booster injections with HCG at 1,000 IU/kg until 10-13 weeks, luteinizing hormone releasing hormone analogue (LHRHa; Sigma-Aldrich) at $400 \mu \mathrm{g} / \mathrm{kg}$ weekly for 13 weeks, and Salmon pituitary extract (SPE; Syndel, Nanaimo, BC, Canada) at $25 \mathrm{mg} /$ fish weekly for 13 weeks. A Pit tag (Destron technologies, USA) was embedded in the muscle of the hormone treated fish for individual identification. Fishes were reared at water temperature of $16^{\circ} \mathrm{C}$ in FRP tank containing 3,000 liters of seawater during the experimental period. Measurement of body weight to determine the rate of increased body weight (RIW = 100 - initial body weight / initial body weight) was conducted under anesthesia once a week until 13 weeks after exogenous hormonal injection. After 9 weeks of hormone injection, developmental stages of ovaries were investigated by performing cannulation biopsies on individuals whose body weights was increased by more than $10 \%$. In the second experiment, each of 20 females maintained at water temperature of $12^{\circ} \mathrm{C}$, $14^{\circ} \mathrm{C}$, and $16^{\circ} \mathrm{C}$ were injected intraperitoneally with HCG $1,000 \mathrm{IU} / \mathrm{kg}$ weekly for 8 weeks. Other procedure and methods of the second experiment were the same as the first experiment.

\section{RESULTS}

\section{Effects of water temperature on ovarian development}

Fig. 1 shows changes in GSI of female conger eels at water temperatures of $12^{\circ} \mathrm{C}, 14^{\circ} \mathrm{C}$, and $16^{\circ} \mathrm{C}$. At the start of the experiment, the value of GSI was 3.66. The value of GSI of the fish reared

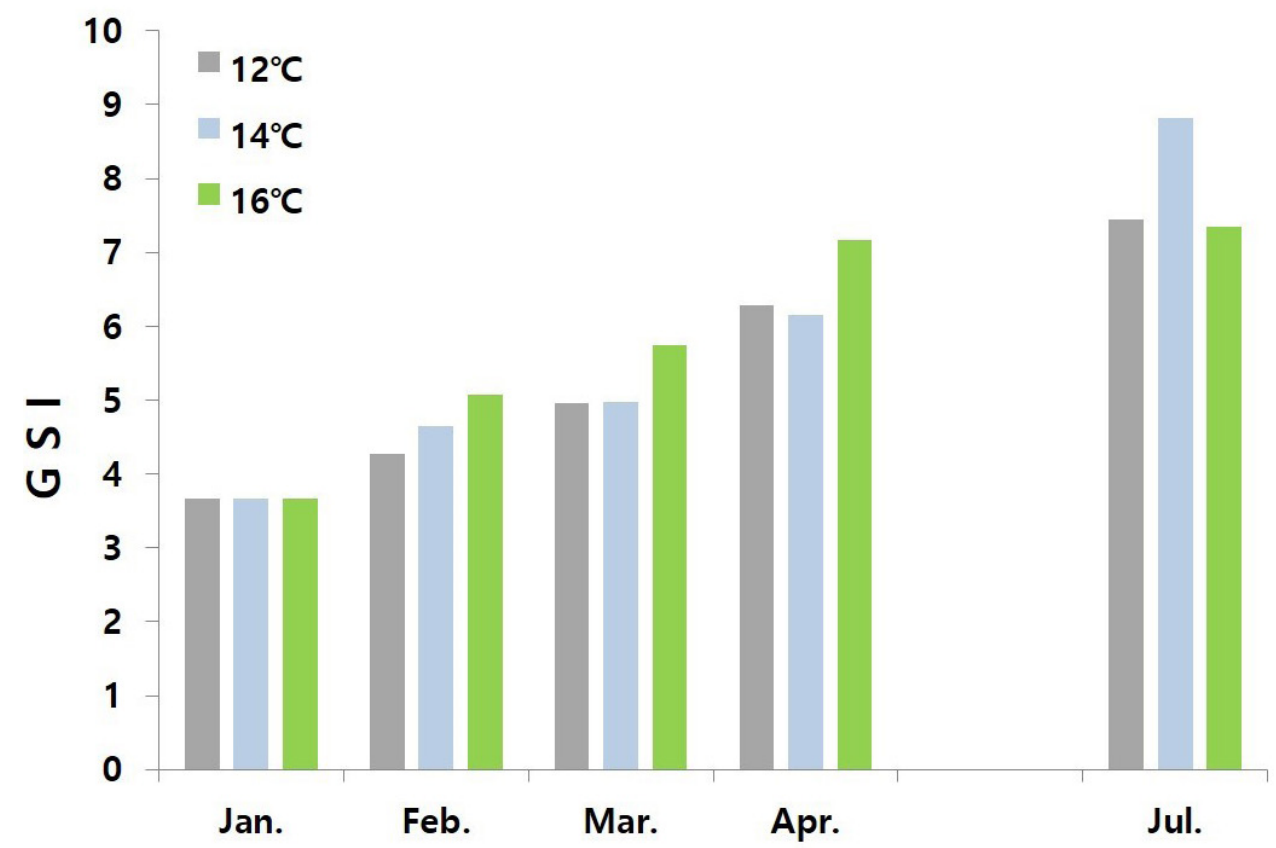

Fig. 1. Changes in gonadosomatic index (GSI) of female conger eels at water temperatures of $12{ }^{\circ} \mathrm{C}$, $14^{\circ} \mathrm{C}$, and $16^{\circ} \mathrm{C}$. 
at water temperature of $12^{\circ} \mathrm{C}$ increased gradually to $4.27,4.96,6.29$, and 7.44 in February, March, April, and July, respectively. The value of GSI of the fish reared at water temperature of $14^{\circ} \mathrm{C}$ increased gradually to $4.65,4.97,6.16$, and 8.82 in February, March, April, and July, respectively. The value of GSI of fish reared at water temperature of $16^{\circ} \mathrm{C}$ increased gradually to $5.07,5.75,7.17$, and 7.34 in February, March, April, and July, respectively.

Fig. 2 shows changes in oocyte diameter of female conger eel at water temperatures of $12^{\circ} \mathrm{C}$, $14^{\circ} \mathrm{C}$, and $16^{\circ} \mathrm{C}$. At the start of experiment, the range of oocyte diameter was $245.11-300.25 \mu \mathrm{m}$. This range of oocyte diameter of fish reared at water temperature of $12{ }^{\circ} \mathrm{C}$ increased gradually to 275.34-310.71 $\mu \mathrm{m}, 301.68-353.45 \mu \mathrm{m}, 320.27-378.24 \mu \mathrm{m}$ and 377.62-480.27 $\mu \mathrm{m}$ in February, March, April and July respectively. The range of oocyte diameter of fish reared at water temperature of $14^{\circ} \mathrm{C}$ increased gradually to $293.52-327.88 \mu \mathrm{m}, 331.63-344.97 \mu \mathrm{m}, 334.72-381.54 \mu \mathrm{m}$, and 396.72-498.54 $\mu \mathrm{m}$ in February, March, April and July respectively. The range of oocyte diameter of the fish reared at water temperature of $16^{\circ} \mathrm{C}$ increased gradually to $257.41-330.41 \mu \mathrm{m}$, 346.31-373.69 $\mu \mathrm{m}, 384.69-469.81 \mu \mathrm{m}$ and 382.29-475.69 $\mu \mathrm{m}$ in February, March, April and July respectively. Histological examination revealed that the follicular oocyte development was in primary yolk globule stage from January to March, and in secondary yolk globule stage from April to July until end of the experiment (Fig. $3 \mathrm{~A}$ and 3B).

\section{Effects of exogenous hormones on ovarian development}

For the first experiment, each of 10 females were intraperitoneally injected with exogenous hormones weekly for 10-13 weeks. Table 1 shows the number of individuals at different levels of RIW and stage of ovarian development after injection with various hormones. The number of individuals in 100\%-110\% and 110\%-120\% of RIW with the HCG $100 \mathrm{IU} / \mathrm{kg}$ was 3 specimens and 4 specimens, respectively after 9 weeks injection ( 3 specimens died), and then the number of fishes after booster injection of HCG 1,000 IU/ $\mathrm{kg}$ changed to 2 specimens in 100\%-110\%, 2 specimens in 110\%-120\%, 1 specimen in 120\%-130\% and 2 specimens in 130\%-140\%. The number of individuals in below 100\% and 100\%-110\% of RIW with HCG 500 IU/kg was 1

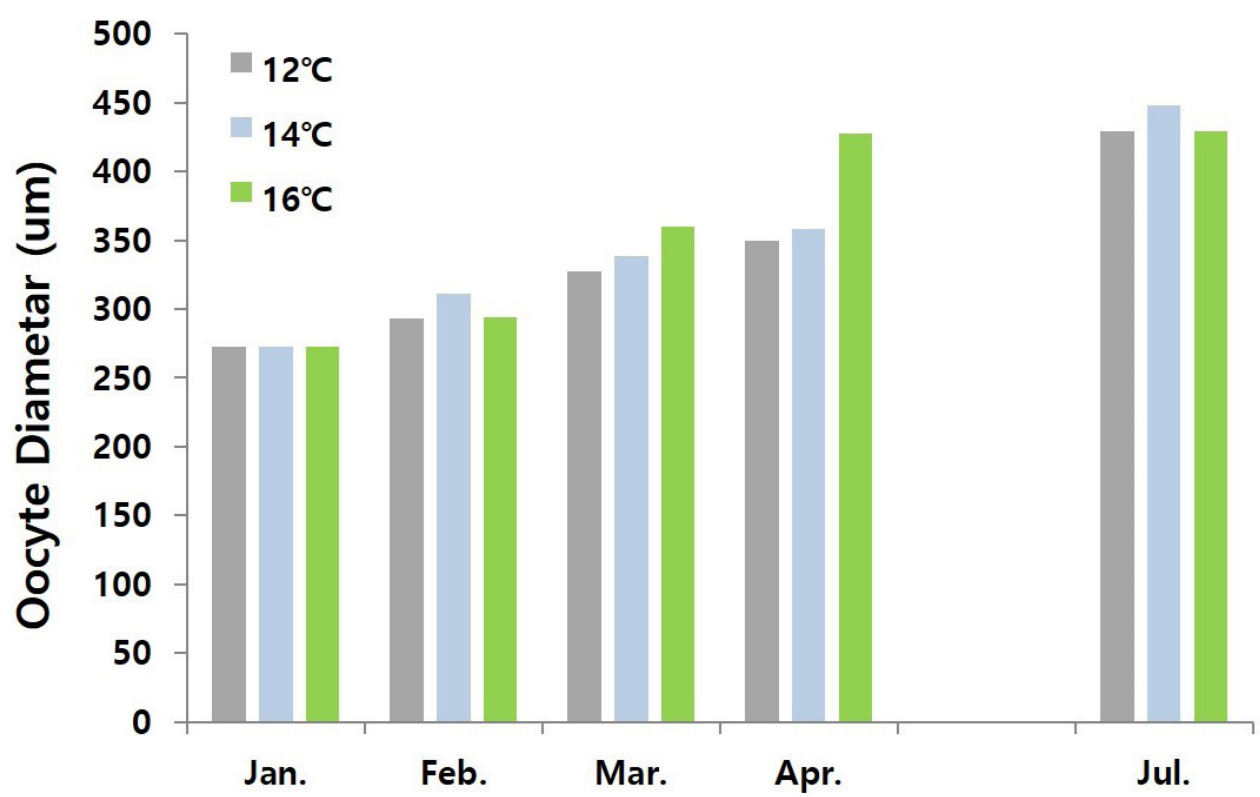

Fig. 2. Changes in oocyte diameters of female conger eels at water temperatures of $12^{\circ} \mathrm{C}, 14^{\circ} \mathrm{C}$, and, $16^{\circ} \mathrm{C}$. 

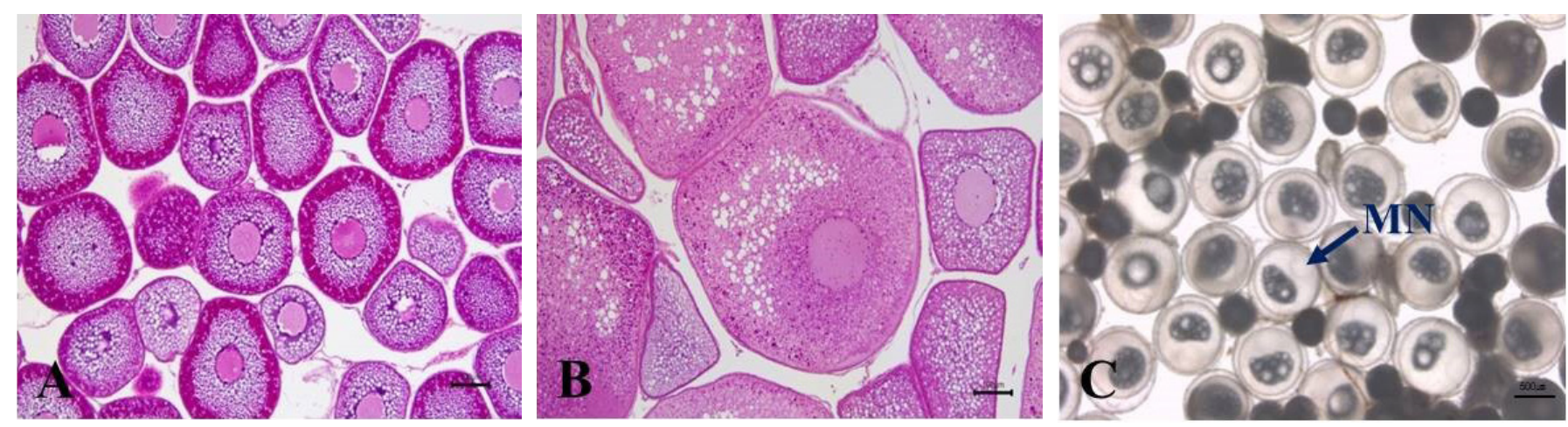

Fig. 3. Photomicrographs showing development of oocyte. (A) PY, primary yolk globule stage. Scale bars=100 $\mu \mathrm{m}$. (B) SY, secondary yolk globule stage. Scale bars $=100 \mu \mathrm{m}$. (C) MN, migratory nucleus stage. Scale bars $=500 \mu \mathrm{m}$.

Table 1. Effects of exogenous hormones on ovarian development of Conger myriaster developmental stages of the largest oocytes

\begin{tabular}{|c|c|c|c|c|c|c|c|c|c|c|}
\hline \multirow{3}{*}{ Treatment } & \multicolumn{5}{|c|}{ No of individuals after 9th (10-13th) injection } & \multicolumn{5}{|c|}{ No of individuals in the end of experiment } \\
\hline & \multicolumn{5}{|c|}{ Rate of increased body weight (\%) } & \multicolumn{5}{|c|}{$\begin{array}{l}\text { Developmental stage of the large oocytes } \\
\text { (Oocyte Diameter, } \mu \mathrm{m})\end{array}$} \\
\hline & $\begin{array}{c}100 \\
\text { below }\end{array}$ & $100-110$ & $110-120$ & $120-130$ & $130-140$ & PY & SY & TY & $\mathrm{MN}$ & GVBD \\
\hline $\begin{array}{l}\text { HCG } \\
(100 \mathrm{IU} / \mathrm{kg})+(1,000 \mathrm{IU} / \mathrm{kg}) \\
\text { from the 9th injection }\end{array}$ & & $3(2)$ & $4(2)$ & $0(1)$ & $0(2)$ & ${ }^{2}(370-470)$ & $\stackrel{2}{(570-667)}$ & & $\begin{array}{c}3 \\
(1,029-1,297)\end{array}$ & \\
\hline $\begin{array}{l}\text { SPE } \\
\text { (25 mg/fish) }\end{array}$ & & $0(1)$ & $3(1)$ & $1(1)$ & $0(1)$ & $\begin{array}{c}1 \\
(250-324)\end{array}$ & $\begin{array}{c}2 \\
(481-685)\end{array}$ & & $\begin{array}{c}1 \\
(837-890)\end{array}$ & \\
\hline $\begin{array}{l}\text { LHRHa } \\
\qquad(400 \mu \mathrm{g} / \mathrm{kg})\end{array}$ & $5(5)$ & $1(0)$ & $0(1)$ & & & $\begin{array}{c}6 \\
(92-350)\end{array}$ & & & & \\
\hline
\end{tabular}

3 fish died at HCG $100 \mathrm{IU} / \mathrm{kg}, 2$ fish died at HCG $500 \mathrm{IU} / \mathrm{kg}, 6$ fish died at SPE $25 \mathrm{mg} / \mathrm{fish}, 4$ fish died at LHRHa $400 \mu \mathrm{gg} / \mathrm{kg}$.

PY, primary yolk globule stage; SY, secondary yolk globule stage; TY, tertiary yolk globule stage; MN, migratory nucleus stage; GVBD, germinal vesicle breakdown stage; HCG, human chorionic gonadotropin.

specimens and 7 specimens, respectively after 9 weeks injection ( 2 specimens died) and then the number of fishes after booster injection of HCG 1,000 IU/kg changed to 4 specimens in 110\%$120 \%, 3$ specimens in 120\%-130\% and 1 specimen in 130\%-140\%. The number of individuals in 110\%-120\% and 120\%-130\% of RIW with SPE $25 \mathrm{mg} /$ fish was 3 specimens and 1 specimen (6 specimens died), respectively after 9 week later and then changed to 1 specimen in $100 \%-110 \%$, 1 specimen in 110\%-120\%, 1 specimen in 120\%-130\% and 1 specimen in 130\%-140\% after 13 weeks injection. The number of individuals in below $100 \%$ and $100 \%-110 \%$ of RIW with LHRHa $400 \mu \mathrm{g} / \mathrm{kg}$ was 5 specimens and 1 specimen (4 specimens died), respectively after 9 week later and then changed to 5 specimens in below $100 \%$ and 1 specimen in $110 \%-120 \%$.

Fishes injected with HCG $100 \mathrm{IU} / \mathrm{kg}$ and booster shot of HCG 1,000 IU/kg showed different ovarian developmental stages at the end of experiment; 2 specimens (oocyte diameter 370-470 $\mu \mathrm{m}$ ) were at the primary yolk globule, 2 specimens $(570-667 \mu \mathrm{m})$ were at the secondary yolk globule and 3 specimens $(1,029-1,297 \mu \mathrm{m})$ were at the migratory yolk globule (Fig. 3C). However, fishes injected with HCG at $500 \mathrm{IU} / \mathrm{kg}$ and booster shot of HCG 1,000 IU/kg showed slower rate of gonadal development at the end of the experiment than previous treatment, 7 specimens (530-720 $\mu \mathrm{m})$ at the secondary yolk globule and 1 specimen $(851-987 \mu \mathrm{m})$ at the migratory yolk globule. 
After injecting SPE at $25 \mathrm{mg} /$ fish, the primary yolk globule, the secondary yolk globule and the migratory yolk globule stages of ovarian development were found in 1 specimen (oocyte diameter 250-324 $\mu \mathrm{m}), 2$ specimens $(481-685 \mu \mathrm{m})$ and 1 specimens $(837-890 \mu \mathrm{m})$, respectively. After injecting LHRHa at $400 \mu \mathrm{g} / \mathrm{kg}$, the stages of ovarian of all experimental fishes were in the primary yolk globule (oocyte diameter 92-350 $\mu \mathrm{m}$ ).

\section{Effects of water temperature on ovarian development after injection with human chori- onic gonadotropin (HCG) 1,000 IU/kg}

Table 2 shows numbers of individuals at different levels of RIW and stages of ovarian development at water temperatures of $12{ }^{\circ} \mathrm{C}, 14^{\circ} \mathrm{C}$, and $16^{\circ} \mathrm{C}$ after injecting $\mathrm{HCG}$ at $1,000 \mathrm{IU} / \mathrm{kg}$. Each of 20 females was intraperitoneally injected with HCG at 1,000 IU/kg weekly for 8 weeks. At water temperature of $12^{\circ} \mathrm{C}, 2,10$ and 7 specimens had RIW of 110\%-120\%, 120\%-130\%, and $130 \%-140 \%$, respectively. At water temperature of $14^{\circ} \mathrm{C}, 1,9$, and 8 specimens had RIW of 110\%-120\%, 120\%-130\%, and 130\%-140\%, respectively. At water temperature of $16^{\circ} \mathrm{C}, 5,10$, and 5 specimens had RIW of 110\%-120\%, 120\%-130\% and 130\%-140\%, respectively. On regarding ovarian development at water temperatures of $12^{\circ} \mathrm{C}, 14^{\circ} \mathrm{C}$, and $16^{\circ} \mathrm{C}, 19,18$ and 20 specimens were found to be in secondary yolk globule stage, migratory nucleus stage, and secondary yolk globule stage respectively.

\section{DISCUSSION}

Research on conger eels is mainly conducted in the field of ecology and biological resources such as feeding ecology (Huh \& Kwak, 1998; Jeong et al., 2002; Choi et al., 2008), age and growth (Kim et al., 2011), diet compositions (Kim et al., 2020), and so on. There are very little information on the reproduction of Korean conger eels. Thus, we conducted this experiment.

The reproduction of teleost fishes is controlled by environmental factors such as day length and water temperature (De Vlaming, 1972; Munro, 1990). Manipulation of these environmental factors are proven and useful tool for managing egg production in aquaculture (Pankhurst et al., 1996). In Japanese conger eels that reared in captivity, ovarian development of female progresses to secondary yolk globule stage without exogenous hormone treatment when maintained at water temperature from 10 to $20^{\circ} \mathrm{C}$ (Kajimura et al., 2001; Utoh et al., 2003, 2004,2005; Chiba et al., 2005). However, ovarian development in all females was halted at the secondary yolk globule stage. In the cultured conger eels of korea, the ovarian development of female progressed to the secondary yolk globule

Table 2. Effects of HCG at $1,000 \mathrm{IU} / \mathrm{kg}$ on ovarian development of Conger myriaster at various water temperatures

\begin{tabular}{|c|c|c|c|c|c|c|c|c|c|}
\hline \multirow{3}{*}{ Temp. } & \multicolumn{4}{|c|}{ No of individuals after 8th injection } & \multicolumn{5}{|c|}{ No of individuals in the end of experiment } \\
\hline & \multicolumn{4}{|c|}{ Rate of increased body weight (\%) } & \multicolumn{5}{|c|}{ Developmental stage of the large oocytes (Oocyte diameter, $\mu \mathrm{m}$ ) } \\
\hline & $100-110$ & $110-120$ & $120-130$ & $130-140$ & PY & SY & TY & MN & GVBD \\
\hline $12^{\circ} \mathrm{C}$ & 0 & 2 & 10 & 7 & & $\begin{array}{c}19 \\
(552-790)\end{array}$ & & & \\
\hline $14^{\circ} \mathrm{C}$ & 0 & 1 & 9 & 8 & & & & $\begin{array}{c}18 \\
(890-1,303)\end{array}$ & \\
\hline $16^{\circ} \mathrm{C}$ & 0 & 5 & 10 & 5 & & $\begin{array}{c}20 \\
(564-729)\end{array}$ & & & \\
\hline
\end{tabular}

1 fish died at $12^{\circ} \mathrm{C}, 2$ fish died at $14^{\circ} \mathrm{C}$.

PY, primary yolk globule stage; SY, secondary yolk globule stage; TY, tertiary yolk globule stage; MN, migratory nucleus stage; GVBD, germinal vesicle breakdown stage; HCG, human chorionic gonadotropin. 
stage without exogenous hormone treatments when reared at water temperatures that varied from 12 to $16^{\circ} \mathrm{C}$. It also halted for four months. During the ovarian development of conger eels, diapause of oogenesis in the secondary yolk globule stage in varied range of water temperature needs to be solved in terms of evolutionary strategy of the species.

Values of GSI and oocyte diameter provide valuable information about ovarian development of females. Values of GSI in the primary yolk globule stage and the secondary yolk globule stage were 3.66-5.07 and 5.75-8.82 for conger eels of Korea and 4.33 and 9.70 for Japanese conger eels (Utoh et al., 2003), respectively. Oocyte diameter in the primary yolk globule stage and the secondary yolk globule stage were 245.11-330.41 $\mu \mathrm{m}$ and 320.27-498.54 $\mu \mathrm{m}$ for conger eels of Korea and 200$350 \mu \mathrm{m}$ and 300-500 $\mu \mathrm{m}$ for Japanese conger eels (Utoh et al., 2003), respectively. These GSI values and oocyte diameters of conger eels of Korea were not significantly different from those of Japanese conger eels in captivity, suggesting that our experimental system was successfully established to study ovarian development of conger eels in Korea.

For Japanese conger eels, oocyte maturation and ovulation can be successfully induced by solely changing the water temperature without exogenous hormone treatments (Utoh et al., 2013). However, the rate of ovulation induction was very low and more fertilization was not successful. Horie et al. $(2001 ; 2003)$ reported that maturation and ovulation of oocytes of female conger eels can be induced by repeated injections of HCG at $0.1 \mathrm{IU} / \mathrm{g}$ BW, 17, $20 \beta$-dihydroxy-4-prognen-3one, $17 \alpha$-hyroxyprogesterone (17 $\alpha$-OHP). The progress from the secondary yolk globule stage to maturation of oocyte can be induced by injecting fishes with HCG at $100 \mathrm{IU} / \mathrm{kg}$ every two weeks. However, in female conger of Korea, ovarian development of fish treated with HCG at $100 \mathrm{IU} / \mathrm{kg}$ or $500 \mathrm{IU} / \mathrm{kg}$ for 9 weeks remained at the secondary yolk globule stage. The progress from diapause of the secondary yolk globule stage to migratory nucleus stage of oocytes can be induced by HCG at $1,000 \mathrm{IU} / \mathrm{kg}$. Differences in effects of these hormones might be due to differences of products from different companies. However, further studies are needed to explore other possibilities. SPE is the most effective one among hormones used for inducing ovarian development in female Japanese eels. HCG induced the maturation of oocytes more effectively in both conger eels in Korea and Japanese conger eels than SPE.

The vitellogenesis, maturation and ovulation of oocytes are regulated by a cascade of hormones along the brain-pituitary-gonad (BPG) axis. In this axis, secretion of pituitary gonadotropins is controlled by gonadotropin releasing hormones ( $\mathrm{GnRHs}$ ) from the hypothalamus (Peter \& $\mathrm{Yu}, 1997$; Yu et al., 1997). It is known that synthetic GnRHs are an order of magnitude more potent than their native peptides. The use of $\mathrm{GnRH}$ peptides for ovarian development induction has important advantages over the use of GTH preparations. GnRH and its agonists are small decapeptides that do not trigger an immune response. Thus, they can be used repeatedly without reduction in their efficacy (Zohar \& Mylonas 2001). Female conger eels in Korea treated with LHRHa at $400 \mu \mathrm{g} / \mathrm{kg}$ did not show any response to the hormone. Instead, regression of ovarian development was found. This phenomenon is very rare. Further research is needed to clarify it.

It has been reported that conger eels are very sensitive to handling stress. Many females (between $50 \%$ and $81 \%$ ) will die during the handling associated with repeated injections necessary for inducing maturation. Fertilizable eggs could not be obtained from females that had been handled $>12$ times (Horie et al., 2003). In the present study, ovarian development stage proceeded only to the migration nucleus stage. It was highly likely to be caused by the handling stress.

Anguilla species have similar reproductive life cycles such as extensive oceanic migration for maturity and spawning with leptocephalus stages and metamorphosis to glass eels (Miller et al., 2011). The spawning area of Japanese conger eels based on the survey of preleptocephalus larvae has been suggested to be the area along the Kyushu-Palau Ridge approximately $380 \mathrm{~km}$ south 
of Okinotorishima Island (Kurogi et al., 2012). However, it is still unknown whether conger eels in Korea spawn in the same sea area. The effect of hormone treatment on ovarian development in Japanese conger eel was the most effective at a water temperature of $10^{\circ} \mathrm{C}$. In conger eels of Korea, the effect of hormone treatment on ovarian development was the most effective at a water temperature of $14^{\circ} \mathrm{C}$. In the future, more precise research on breeding water temperature during hormone treatment is needed.

It is the first report on effect of water temperature and hormones on ovarian development of conger eel in Korea. In the future, more effort is needed to obtain high-quality ovulated eggs from female conger eels, but this study is the beginning of a meaningful challenge.

\section{REFERENCES}

Chiba H, Ijiri S, Iwata M, Nakamura M, Adachi S, Yamauchi K (2005) Changes in serum steroid hormones during ovarian development in the captive common Japanese conger Conger myriaster (Brevoort). Aquacult Sci 53:189-198.

Choi JH, Choi SH, Kim JB, Park JH, Oh CW (2008) Feeding ecology of the white-spotted conger eel (Conger myriaster) in the southern sea of Korea. Korean J Fish Aquat Sci 41:282-288.

De Vlaming VL (1972) The effects of temperature and photoperiod on reproductive cycling in the estuarine gobiid fish, Gillichthys mirabilis. Fish Bull 70:1137-1152.

Fueda E, Segawa S, Nakamura N, Yamada S, Chuda H, Kato K, Ohta H (2019) Residual concentrations of human chorionic gonadotropin in female whitespotted conger reared under low water temperatures after a single injection. Aquaculture 509:129-133.

Horie N, Uto T, Yamada S, Okamura A, Zhang M, Mikawa N, Tanaka S, Oka H (2001) Artificial induction of ovarian maturation and ovulation in the common Japanese conger Conger myriaster. Nippon Suisan Gakkaishi 67:842-849.

Horie N, Yamada Y, Okamura A, Tanaka S, Uto T, Mikawa N, Akazawa A, Oka H (2003) Effective hormonal treatments for induction of ovarian maturation and ovulation in the common Japanese conger Conger myriaster. Nippon Suisan Gakkaishi 69:337-346.

Huh SH, Kwak SN (1998) Feeding habits of Conger myriaster in the eelgrass (Zostera marina) bed in Kwangyang bay. Korean J Fish Aquat Sci 31:665-672.

Jeong SB, Lee JH, Kim SH, Oh YT, Cho SK (2002) Analysis of stomach contents of sea-eel Conger myriaster caught from lost plastic pot.J Korean Soc Fish Ocean Technol 38:149-155.

Kajimura S, Yoshiura Y, Suzuki M, Utoh T, Horie N, Oka H, Aida K (2001) Changes in the levels of mRNA coding for gonadotropin I $\beta$ and Ii $\beta$ subunits during vitellogenesis in the common Japanese conger Conger myriaster. Fish Sci 67:1053-1062.

Kim KR, Nam KM, Park KH, Kim BS, Han MI, Kwak JW, Baeck GW (2020) Diet composition of whitespotted conger, Conger myriaster in the coastal waters of Geoje island, Korea. Korean J Ichthyol 32:103-109.

Kim YH, Lee EH, Kim JN, Choi JH, Oh TY, Lee DW (2011) Age and growth of whitespotted conger Conger myriaster in the southern coastal waters of Korea. Korean J Fish Aquat Sci 44:689-694.

Kurogi H, Mochioka N, Okazaki M, Takahashi M, Miller MJ, Tsukamoto K, Ambe D, Katayama S, Chow S (2012) Discovery of a spawning area of the common Japanese conger Conger myriaster along the Kyushu-Palau ridge in the western North Pacific. Fish Sci 78:525-532.

Miller MJ, Yoshinaga T, Aoyama J, Otake T, Mochioka N, Kurogi H, Tsukamoto K (2011) Offshore spawning of Conger myriaster in the western North pacific: Evidence for convergent 
migration strategies of anguilliform eels in the Atlantic and Pacific. Naturwissenschaften 98:537-543.

Munro AD, Scott AP, Lam TJ (1990) Reproductive Seasonality in Teleosts: Environmental Influences. CRC Press, Boca Raton, FL.

Ochiai A, Tanaka M (1986) Maanago. Ichthiology. 2nd ed. Koseisha-Kosei-kaku, Tokyo, Japan, pp 576-580.

Pankhurst NW, Purser GJ, Van Der Kraak G, Thomas PM, Forteath GNR (1996) Effect of holding temperature on ovulation, egg fertility, plasma levels of reproductive hormones and in vitro ovarian steroidogenesis in the rainbow trout, Oncorbynchus mykiss. Aquaculture 146:277290.

Park CD (2001) Conger-eel fisheries in Korea. Nippon Suisan Gakkaishi 67:127-128.

Peter RE, Yu KL (1997) Neuroendocrine regulation of ovulation in fishes: Basic and applied aspects. Rev Fish Biol Fish 7:173-197.

Statistics Korea. (2015, 2020). Korean Statistical Information System (KOSIS). Available from: http://kosis.kr/index/index.do. Access at Nov 30, 2021.

Tokimura M (2001) Conger-eel fisheries and fisheries resources in the East China Sea. Nippon Suisan Gakkaishi 67:125-126.

Utoh T, Horie N, Okamura A, Yamada Y, Tanaka S, Mikawa N, Akazawa A, Oka H (2003) Oogenesis in the common Japanese conger Conger myriaster. Fish Sci 69:181-188.

Utoh T, Horie N, Mikawa N, Okamura A, Yamada Y, Akazawa A, Tanaka S, Oka HP (2005) Annual changes in ovarian development and plasma estradiol-17 $\beta$ level in reared female common Japanese conger, Conger myriaster. Fish Sci 71:38-47.

Utoh T, Horie N, Okamura A, Mikawa N, Yamada Y, Tanaka S, Oka HP, Tsukamoto K (2013) Water temperature manipulation can induce oocyte maturation and ovulation in the common Japanese conger, Conger myriaster. Aquaculture 392-395:120-127.

Utoh T, Okamura A, Yamada Y, Tanaka S, Mikawa N, Akazawa A, Horie N, Oka HP (2004) Reproductive cycle in reared male common Japanese conger, Conger myriaster. Aquaculture 240:589-605.

Yu KL, Lin XW, da Cunha Bastos J, Peter RE (1997) Neural regulation of GnRH in teleost fishes. In: Parhar IS, Sakuma Y (eds), GnRH Neurons: Gene to Behavior. Brain Shuppan, Tokyo, Japan, pp 277-312.

Zohar Y, Mylonas CC (2001). Endocrine manipulations of spawning in cultured fish: From hormones to genes. In: Lee CS, Donaldson EM (eds), Reproductive Biotechnology Finfish Aquaculture. Elsevier, Burlington, MA, pp 99-136. 
